Available online at http://journal.stkip-andi-matappa.ac.id/index.php/histogram/index

Histogram : Jurnal Pendidikan Matematika ., 2019, 218 - 227

\title{
PROSES BERPIKIR KREATIF MAHASISWA DALAM PEMECAHAN MASALAH MATEMATIKA BERDASARKAN GENDER
}

\author{
Andi Yunarni Yusri ${ }^{1}$ Febria Hardianty ${ }^{2}$ \\ ${ }^{1}$ STKIP Andi Matappa \\ ${ }^{2}$ STIMIK Lamappapoleonro \\ * Corresponding Author. Email: yunarniyusri@gmail.com
}

Received: 25 Juli 2019; Revised: 18 Agustus 2019 ; Accepted: 30 September 2019

\begin{abstract}
ABSTRAK
Penelitian ini merupakan penelitian kualitatif yang bertujuan untuk memperoleh deskripsi proses berpikir kreatif mahasiswa berdasarkan perbedaan gender. Instrumen dalam penelitian ini adalah peneliti sendiri sebagai instrumen utama yang dipandu oleh tugas pemecahan masalah matematika dan pedoman wawancara yang valid dan reliabel. Pengumpulan data dilakukan dengan wawancara berbasis tugas. Subjek penelitian adalah mahasiswa semester VII Program studi Pendidikan Matematika STKIP Andi Matappa yang terdiri dari dua orang (1 orang laki-laki dan 1 orang perempuan). Hasil penelitian menunjukkan: (1) Tidak terdapat perbedaan yang berarti tentang proses berpikir kreatif subjek laki-laki (S1) dan subjek perempuan (S2) dalam pemecahan masalah matematika yang memenuhi aspek lancar (fluent), fasih (flexible) dan baru (original), yaitu keduanya melalui tahapan: 1) persiapan, 2) inkubasi, 3) iluminasi, dan 4) verifikasi. Demikian pula, tidak ditemukan perbedaan yang berarti tentang rangkaian aktivias mental yang digunakan kedua subjek pada tiap tahapan; (2) Ditemu kenali perbedaan hasil tugas kedua subjek: 1) S1 menggunakan tiga cara yang baru, meskipun ketiga cara ini menggunakan konsep yang sama. Sedang S2, menggunakan satu cara baru, 2) fungsi-fungsi yang ditemukan S1 lebih variatif dan lebih kompleks dibanding fungsi-fungsi yang ditemukan S2. Meskipun hasil tugas kedua subjek berbeda,namun keduanya kreatif dalam pemecahan masalah matematika.
\end{abstract}

Kata Kunci : berpikir kreatif, pemecahan masalah, gender

How to Cite: Yusri, A, Y., \& Hardianty, F. (2019). Proses Berpikir Kreatif Mahasiswa dalam Pemecahab Masalah Matematika berdasarkan Gender. Histogram: Jurnal Pendidikan Matematika, 3(2), 218 - 2019, doi: http://dx.doi.org/10.31100/histogram.v3i2.486

Permalink/DOI: http://dx.doi.org/10.31100/histogram.v3i2.486

\section{PENDAHULUAN}

Definisi berpikir dikemukakan oleh banyak ahli secara berbeda sesuai dengan sudut pandang masing-masing. (Dharma, 2008), mendefinisikan berpikir sebagai aktivitas mental yang dilakukan seseorang dalam mengolah informasi untuk mengambil keputusan perilaku. Definisi ini mengisyaratkan bahwa berpikir diawali oleh masuknya informasi atau masalah, kemudian informasi itu diolah dalam pikiran yang selanjutnya menghasilkan keputusan perilaku.

Berdasarkan tingkatnya, berpikir terbagi dua, yaitu berpikir tingkat rendah dan berpikir tingkat tinggi. Menghafal, mengingat, membandingkan, membayangkan, This is open access article under the CC-BY-SA-license. 


\section{Histogram: Jurnal Pendidikan Matematika, 3 (2), 2019 - 219 Andi Yunarni Yusri, Febria Hardianty}

mengelompokkan, mengorganisasikan, dan menghubung-hubungkan termasuk berpikir tingkat rendah. Sedang, berpikir kritis, berpikir kreatif dalam pemecahan masalah, dan pengambilan keputusan termasuk berpikir tingkat tinggi (Alimuddin, 2009; Novak, 1979)

Salah satu jenis berpikir tingkat tinggi yang saat ini mendapatkan perhatian yang sangat luas di kalangan ahli psikologi kognitif dan menjadi tujuan pendidikan di setiap negara adalah berpikir kreatif atau kreativitas (Simonton, 2003). Berpikir kreatif dan kreativitas didefinisikan oleh banyak ahli secara berbeda. Beberapa ahli mendefinisikan berpikir kreatif sama dengan kreativitas, namun tidak sedikit yang berpandangan bahwa berpikir kreatif berbeda dengan kreativitas.

Dalam kaitannya dengan matematika, definisi berpikir kreatif telah didefinisikan oleh banyak ahli. Hasil abstraksi pendapat ahli tersebut, disimpulkan bahwa definisi berpikir kreatif dalam matematika atau kreativitas matematika yang dikemukakan oleh ahli merupakan adopsi dari definisi berpikir kreatif dan kreativitas secara umum. Namun, pendapat ahli tersebut di atas dipengaruhi oleh heuristik Polya, sehingga lebih menekankan pada ranah kognitif, yaitu proses dan produk. Proses meliputi identifikasi masalah, menemukan masalah, menemukan kesenjangan dalam informasi, menemukan kekurangan informasi, menemukan sesuatu yang unik, membuat dugaan atau hipotesis, mengevaluasi dan menguji hipotesis dan mungkin merevisi dan menguji kembali hipotesis, dan akhirnya mengkomunikasikan hasil.

(Hwang, W, Y., Chen, N,S., Dung, J, J., \& Yang, Y, 2007) menyatakan: 1) pemecahan masalah matematika adalah usaha sadar yang dilakukan oleh individu untuk menemukan solusi dari masalah matematika, 2) pemecahan masalah matematika dapat meningkatkan kemampuan berpikir tingkat tinggi. Kemampuan berpikir tingkat tinggi bercirikan: tidak algoritmik, cenderung lebih kompleks, menghasilkan beragam solusi, melibatkan beragam kriteria dan proses berpikir, melihat struktur dalam keteraturan, dan melibatkan upaya mental secara mendalam, 3) berpikir kritis, berpikir kreatif, dan pemecahan masalah matematika saling berkomplementer, namun di lain pihak saling membutuhkan satu sama lain. Pemecahan masalah open-ended dapat dijadikan wahana untuk mengungkap berpikir kreatif, yaitu berhubungan dengan berpikir divergen dalam menyelesaikan masalah, 4) kemampuan berpikir kreatif diperlukan untuk memecahkan masalah matematika yang bersifat open-ended, khususnya masalah kompleks.

Pertanyaannya sekarang adalah bagaimana merancang model, strategi, pendekatan, dan metode pembelajaran kreatif yang dapat diterapkan pada kelas yang heterogen, khususnya heterogen dalam jenis kelamin?" 


\section{Histogram: Jurnal Pendidikan Matematika, 3 (2), 2019 - 220 Andi Yunarni Yusri, Febria Hardianty}

Perbedaan gender adalah perbedaan bawaan laki-laki dan perempuan yang dapat berubah setiap saat melalui upaya yang dilakukan. Kognitif adalah salah satu aspek bawaan laki-laki dan perempuan yang dapat berubah dan berkembang setiap saat. Dengan demikian, perbedaan proses berpikir laki-laki dan perempuan, termasuk perbedaan gender. Perbedaan gender ini, menarik minat para ahli dalam melakukan penelitian. Khususnya penelitian yang terkait dengan kemampuan berpikir kreatif atau kreativitas.

Maka peneliti tertarik untuk mengadakan penelitian tentang Proses Berpikir Kreatif Mahasiswa Matematika berdasarkan Gender. Berdasarkan latar belakang yang telah dikemukakan di atas, maka tujuan penelitian ini adalah untuk mengetahui: "Bagaimana proses berpikir kreatif mahasiswa matematika berdasarkan gender".

\section{METODE PENELITIAN}

\section{A. Jenis Penelitian}

Jenis penelitian ini adalah penelitian eksploratif dengan pendekatan kualitatif. Penelitian ini berusaha menggali proses berpikir kreatif mahasiswa dalam pemecahan masalah matematika berdasarkan gender. Proses berpikir kreatif mahasiswa dalam pemecahan masalah matematika dapat dilihat dari perilaku mahasiswa dalam menyelesaikan tugas pemecahan masalah matematika yang mencerminkan aktivitas mentalnya. Perilaku mahasiswa akan ditelusuri dari hasil pekerjaan tertulis, dan wawancara mendalam.

\section{B. Setting Penelitian}

1. Waktu dan Lokasi Penelitian

Penelitian ini akan dilaksanakan di STKIP Andi Matappa Pada program Studi Pendidikan Matematika pada tahun ajaran 2018/2019. Calon subyek penelitian adalah mahasiswa semester VI.

2. Subjek Penelitian

Subjek penelitian ini minimal 2 orang yang terdiri dari 1 laki-laki dan 1 perempuan. Selanjutnya, untuk menentukan subjek penelitian, dilakukan langkah- langkah sebagai berikut:

a. Menetapkan kelas penelitian, yaitu mahasiswa program studi pendidikan Matematika STKIP Andi Matappa (semester VII).

b. Memberikan tugas pemecahan masalah matematika (TPMM) kepada mahasiswa 


\section{Histogram: Jurnal Pendidikan Matematika, 3 (2), 2019 - 221 Andi Yunarni Yusri, Febria Hardianty}

untuk memilih subjek penelitian. Mahasiswa dikatakan kreatif, jika cara/jawaban mahasiswa dari masalah matematika yang diberikan (TPMM) memenuhi salah satu dari: 1) mengemukakan minimal satu cara baru yang tepat dan menggunakannya dalam menemukan beberapa jawaban akhir benar meskipun tidak baru, 2) mengemukakan beberapa cara yang tepat meskipun tidak baru, namun dapat menggunakannya dalam menemukan minimal satu jawaban akhir yang baru. Untuk mempersingkat penulisan, maka kriteria mahasiswa kreatif disingkat" KMK". baru (original) (baru bagi mahasiswa) diartikan sebagai cara yang digunakan atau jawaban akhir yang dikemukakan mahasiswa dalam pemecahan masalah matematika tidak lazim bagi mahasiswa pada umumnya atau cara/jawaban yang dikemukakan mahasiswa belum pernah dijumpai sebelumnya yang bias berupa kaitan beberapa konsep matematika atau kombinasi dari beberapa cara yang pernah dijumpai sebelumnya

\section{Instrumen Penelitian}

Instrumen dalam penelitian ini adalah peneliti sendiri sebagai instrumen utama yang dipandu dengan lembar Tugas Pemecahkan Masalah Matematika (TPMM), pedoman wawancara (PW), dan Tugas Pemecahan Masalah Kreatif. Dalam hal ini, peneliti merupakan perencana, pelaksana pengumpul data, penganalisis, penafsir data, dan akhirnya menjadi pelapor hasil penelitian. Lebih jauh, (Moleong, 2006) mengungkapkan beberapa hal yang perlu diperhatikan perannya peneliti sebagai instrumen:

1. Responsif: peneliti sebagai instrumen hendaknya memiliki sifat responsif terhadap lingkungan dan pribadi-pribadi yang menciptakan lingkungan.

2. Dapat menyesuaikan diri: peneliti sebagai instrumen harus dapat menyesuaikan diri dengan keadaan dan situasi pengumpulan data.

3. Menekankan keutuhan: peneliti sebagai instrumen harus mampu memanfaatkan imajinasi, kreativitasnya.

4. Mendasarkan diri atas perluasan pengetahuan: peneliti sebagai instrumen dapat berdasarkan pengalaman-pengalaman praktisnya.

5. Segera memproses data yang telah diperoleh,menyusunnya kembali, mengubah arah inkuiri atas dasar temuannya, merumuskan hipotesis dan mengetes hipotesis terhadap respondennya.

6. Memanfaatkan kesempatan untuk mengklarifikasi dan mengikhtisarkan: peneliti 


\section{Histogram: Jurnal Pendidikan Matematika, 3 (2), 2019 - 222 Andi Yunarni Yusri, Febria Hardianty}

sebagai instrumen mampu menjelaskan sesuatu yang kurang dipahami oleh subjek atau responden.

7. Memanfaatkan kesempatan untuk mencari respon yang tidak lazim

\section{Pengumpulan Data dan Validasi Data}

Proses pengumpulan data dalam penelitian ini menggunakan interview berbasis tugas, di mana subjek diberi kertas dan pensil untuk mengerjakan Tugas Pemecahan Masalah Matematika (TPMM), kemudian subjek di minta menceritakan secara rinci proses berpikirnya. Selanjutnya, dilakukan interview klinis dan observasi untuk menelusuri alasan, mengapa mengambil kesimpulan itu dan kemungkinan-kemungkinan pemecahan lain yang dapat dilakukan, hasil wawancara didokumentasikan dengan handycam. Proses ini disebut metode Think Out Loud.

Langkah-langkah pengumpulan dan validasi data dalam penelitian ini adalah:

1. Dilakukan pengambilan data dengan cara subjek diberikan TPMM-01 dan TPMM 02 pada waktu yang berbeda. Pada saat subjek mengerjakan TPMM-01 dan TPMM 02 dilakukan wawancara berbasis tugas dan direkam. Hasil rekaman wawancara dibuatkan transkrip yang dilengkapi dengan kode. Data dari TPMM 01 dan TPMM 02 berupa: transkrip wawancara, hasil tugas, dan catatan lapangan dimasukkan dalam bundel yang berbeda (bundel I: kumpulan data TPMM 01, bundel II: kumpulan data TPMM 02)

2. Dilakukan triangulasi waktu dengan cara: data TPMM 01 dan data TPMM 02 dibandingkan. Jika hasil dari triangulasi ini, menunjukkan bahwa data TPMM 01 konsisten, maka diperoleh data yang valid, dan data TPMM 01 dijadikan acuan dalam menganalisis data untuk menjawab pertanyaan penelitian

3. Jika hasil triangulasi yang dilakukan menunjukkan bahwa data TPMM 01 tidak konsisten, maka dilakukan pengambilan data tahap ke-i dengan cara subjek diberi TPMM ke-i, $i \geq 3$. Data ke-i dibandingkan dengan data ke $i-j, j=1,2, . . i-1$. Hal ini dilakukan berulangkali sampai diperoleh data valid.

\section{E. Teknik Analisis Data}

Data yang telah terkumpul dan masih dalam bentuk rekaman, selanjutnya ditransformasi ke dalam bentuk transkrip wawancara. Hasil transkrip dan hasil tugas pemecahan masalah, serta perilaku fisik yang ditunjukkan subjek penelitian dianilisis dengan langkah-langkah sebagai berikut: 


\section{Histogram: Jurnal Pendidikan Matematika, 3 (2), 2019 - 223 Andi Yunarni Yusri, Febria Hardianty}

1. Menelaah Data

Data yang tersedia dari berbagai sumber, yaitu hasil wawancara, hasil pengamatan, catatan lapangan, dan hasil tugas pemecahan masalah matematika ditelaah dengan cara membaca berulang kali.

2. Melakukan Reduksi Data

Data yang terkumpul biasanya sangat bervariasi, tidak teratur, kompleks dan rumit. Oleh karena itu, diperlukan reduksi data dengan cara: membuat rangkuman yang terdiri dari: inti, proses, dan pernyataan-pernyataan yang perlu dijaga agar tetap berada dalam tujuan penelitian. Reduksi data mengacu pada proses pemilihan, pemusatan perhatian dalam hal: penyederhanaan, pengabstraksian, dan transformasi data mentah lapangan. Apabila terdapat data yang tidak valid, maka data itu dikumpulkan tersendiri dan mungkin dapat digunakan sebagai verifikasi ataupun hasil-hasil samping yang lain. Dengan demikian, data yang direduksi akan memberikan gambaran yang lebih spesifik dan mempermudah peneliti untuk melakukan pengumpulan data selanjutnya dan mencari data tambahan, jika diperlukan serta mempermudah untuk melakukan verifikasi data.

3. Penyajian (display) Data

Setelah data direduksi, langkah analisis selanjutnya adalah penyajian (display) data. Penyajian data diarahkan agar data hasil reduksi terorganisasi, tersusun dalam pola hubungan, sehingga makin mudah dipahami. Dalam penelitian ini, akan disusun data yang relevan dengan indikator pada tiap tahapan sesuai urutan aktivitas mental yang dilakukan oleh subjek penelitian. Hal ini dimaksudkan agar informasi yang diperoleh dapat dengan mudah disimpulkan dan memiliki makna tertentu.

4. Membuat Coding

Untuk memudahkan dalam pengkategorian dan menjaga data tetap dalam tujuan penelitian, diperlukan pengkodean data

\section{HASIL DAN PEMBAHASAN}

\section{A. Hasil Penelitian}

Adapun perbedaan berpikir S1 dan S2 dalam Pemecahan Masalah Matematika yaitu :

1. Tahap Persiapan

Perbedaan yang ditemu kenali pada tahap ini adalah, dalam memikirkan jawaban yang berbeda. S1 mencoba kombinasi 2 fungsi linier dan satu fungsi kuadrat (S11-029). 


\section{Histogram: Jurnal Pendidikan Matematika, 3 (2), 2019 - 224 Andi Yunarni Yusri, Febria Hardianty}

Sedangkan, S2 mencoba kombinasi fungsi rasional

2. Tahap Inkubasi

Perbedaan yang ditemukenali pada tahap ini adalah: kegiatan yang dilakukan S1 selama istrahat adalah main internet, berbincang dengan temannya, bersandar di tembok sambil menatap kampus Sedangkan, S2 melakukan kegiatan: ke belakang, berbincang dengan temannya sambil menonton televisi. Sedangkan transisi dari inkubasi keiluminasi, juga menunjukan perbedaan, yaitu Transisi dari inkubasi ke iluminasi yang dilakukan S1 adalah bersandar ditembok sambil menatap taman kampus (TPMM-01) dan mengerjakan soal mahasiswa (TPMM-02), sedangkan transisi yang dilakukan oleh S2 dari inkubasi ke iluminasi adalah menonton TV sambil berbincang dengan temannya (TPMM-01) ) dan sementara sholat (TPMM-02).

\section{Tahap Iluminasi}

Perbedaan yang ditemukenali pada tahap ini adalah: a) Pada saat S1 bersandar di tembok sambil melihat taman kampus, tiba-tiba muncul suatu ide dalam pikirannya Sedangkan, munculnya ide secara tiba-tiba dalam pikiran S2, pada saat S2 menonton TV sambil berbincang-bincang dengan temannya, b) Ide yang muncul secara tiba-tiba dalam pikiran S1 adalah soal yang pernah dijumpai sebelumnya, yaitu diketahui komposisi tiga fungsi dan dua fungsi yang lain, kemudian yang ditanyakan salah satu fungsinya Sedangkan, ide yang tiba-tiba muncul dalam pikiran S2 adalah soal yang pernah dijumpai sebelumnya, yaitu diketahui komposisi 2 fungsi, dan salah satu fungsi yang lain, dan yang ditanyakan adalah salah satu fungsinya, 3) Ide yang ditemukan S1 adalah menetapkan dua fungsi sembarang, kemudian mencari fungsi yang lain. Sedangkan, ide yang ditemu menetapkan fungsi $\mathrm{f}$ dan $\mathrm{g}$, kemudian memisalkan Selanjutnya, menyederhanakan masalah dari komposisi 3 fungsi menjadi komposisi 2 fungsi

\section{Tahap Verifikasi}

Perbedaan yang ditemukan pada tahap ini adalah: dalam menetapkan 2 fungsi, S1 tidak memperhatikan keterkaitan kedua fungsi tersebut atau dengan kata lain penetapan fungsi f tidak mempertimbangkan fungsi g, begitupun sebaliknya, Sedangkan, S2 memperhatikan keterkaitan kedua fungsi tersebut atau dengan kata lain fungsi $f$ mempertimbangkan fungsi $\mathrm{g}$, sedemikian hingga hasilkan fungsi sederhana. Hal tersebut di atas menunjukkan bahwa, S1, S2 : 1) mengumpulkan informasi-informasi berupa konsep-konsep, sifat-sifat matematika, dan soal-soal dengan cara melakukan pememanggilan kembali pengetahuan-pengetahuan yang tersimpan pada memori jangka panjangnya, 2) mensintesis ide yaitu, menetapkan pengetahuan- pengetahuan yang 


\section{Histogram: Jurnal Pendidikan Matematika, 3 (2), 2019 - 225 Andi Yunarni Yusri, Febria Hardianty}

relevan dengan masalah yang dihadapi dan melakukan interpretasi hubungan-hubungan antara pengetahuan-pengetahuan yang relevan dengan tujuan yang akan dicapai, 3) membangun ide/gagasan dengan cara menjalin/mengaitkan pengetahuan-pengetahuan yang relevan dengan masalah pada TPMM, 4) menemukan cara prosedural (cara cobacoba), 5) mengimplementasikan cara coba-coba, 6) mengambil keputusan dengan kesadaran berpikir bahwa, cara coba-coba tidak dapat diterapkan dalam mencari jawaban selain fungsi linier.

Proses berpikir kreatif S1 dan S2 dalam pemecahan masalah matematika yang memenuhi aspek lancar (fluent), fasih (flexible) dan baru (original) dari masalah matematika yang diberikan melibatkan berpikir kreatif dalam aspek afektif, yaitu: 1) kedua subjek mengalami transisi dari inkubasi keiluminasi, yaitu jenuh berpikir dan cenderung putus asaSebelum kedua subjek mengalami inkubasi, keduanya mengalami transisi melalui proses berpikir secara siklis yang disusul dengan rasa jenuh berpikir dan cenderung putus asa (DTL-1), 2) S1 dan S2 berpikir keras untuk menemukan cara dan jawaban yang lain, karena keduanya merasa tertantang (DTL-2). Data ini menunjukkan bahwa, proses berpikir kreatif S1 dan S2 dalam menemukan jawaban yang memenuhi kelancaran, fleksibilitas, dan kebaruan melibatkan aspek afektif.

Ide kunci yang muncul pada saat iluminasi telah terpikirkan kedua subjek pada saat persiapan, namun, S1 dan S2 tidak dapat mengembangkan menjadi suatu ide yang tepat. Sedangkan, pada saat iluminasi, ide tersebut dapat dikembangkan menjadi ide yang tepat (DTL-2). Hal ini menunjukkan bahwa kedua subjek mengalami kekakuan fungsional (functional fixedness),yaitu keduanya terlalu memfokuskan pada realitas masalah, sehingga cara berpikirnya cenderung analitik dan prosedural dan terbelenggu dengan cara-cara lama dan memfokuskan pemikirnnya pada memori jangka pendek. Hal ini berdampak pada terfokusnya pemikiran pada objek fisik (konsep-konsep yang secara eksplisit nampak pada masalah), sehingga kedua subjek cenderung mempertahankan pemikirannya tetap stabil. Akibatnya, kedua subjek pada tahap persiapan gagal melihat ciri-ciri suatu stimulus lain yang mungkin berguna dalam pemecahan masalah matematika yang diberikan.

Kedua subjek mampu mengembangkan ide untuk digunakan dalam menyelesaikan masalah matematika yang serupa dengan derajat kesulitan yang lebih tinggi. Hal ini menunjukkan bahwa kedua subjek cenderung menggali gagasan-gagasan baru. $(D T L-3)$ 


\section{Histogram: Jurnal Pendidikan Matematika, 3 (2), 2019 - 226 Andi Yunarni Yusri, Febria Hardianty}

\section{B. Pembahasan}

1. Tidak ada perbedaan secara signifikan proses berpikir kreatif mahasiswa dalam pemecahan masalah matematika berdasarkan gender. Hasil penelitian beberapa ahli yang mendukung penelitian ini, antara lain: (Agarwal, S. \& Kumari, 1982; Alpaugh, P. K. \& Birren, 1977; Bromley, 1956; Jaquish, G. A. \& Ripple, 1981), yang mengungkapkan bahwa tidak ada perbedaan secara signifikan antara laki-laki dan perempuan dalam berpikir kreatif. Sedangkan, (Baer, 1993) mengungkapkan bahwa dari 80 studi yang yang berkaitan dengan kreativitas, setengah dari studi ini melaporkan bahwa tidak ada perbedaan kemampuan berpikir kreatif antara laki-laki dan perempuan, sekitar dua-pertiga dari studi yang tersisa menyatakan wanita lebih kreatif, sedangkan sepertiganya menyatakan laki-laki lebih kreatif.

2. Proses berpikir kreatif mahasiswa, baik subjek laki-laki (S1), maupun subjek perempuan (S2) mengikuti tahapan: (1) persiapan, (2) inkubasi, (3) iluminasi, dan (4) verifikasi. Temuan ini didukung oleh temuan (Sriraman, 2004) yang menyimpulkan bahwa proses berpikir kreatif ilmuwan melalui tahapan: persiapan, inkubasi, iluminasi, dan verifikasi.

\section{KESIMPULAN DAN SARAN}

Berdasarkan hasil penelitian dan pembahasan yang dilakukan, maka diperoleh kesimpulan dalam penelitian ini, sebagai berikut: (1) Tidak terdapat perbedaan yang berarti tentang proses berpikir kreatif subjek laki-laki (S1) dan subjek perempuan (S2) dalam pemecahan masalah matematika yang memenuhi aspek lancar (fluent), fasih (flexible) dan baru (original), yaitu keduanya melalui tahapan: 1) persiapan, 2) inkubasi, 3) iluminasi, dan 4) verifikasi. Demikian pula, tidak ditemukan perbedaan yang berarti tentang rangkaian aktivias mental yang digunakan kedua subjek pada tiap tahapan; (2) Ditemu kenali perbedaan hasil tugas kedua subjek: 1) S1 menggunakan tiga cara yang baru, meskipun ketiga cara ini menggunakan konsep yang sama. Sedang S2, menggunakan satu cara baru, 2) fungsi-fungsi yang ditemukan S1 lebih variatif dan lebih kompleks dibanding fungsi-fungsi yang ditemukan S2. Meskipun hasil tugas kedua subjek berbeda, namun keduanya kreatif dalam pemecahan masalah matematika. Adapun saran sebagai berikut: Agar diperoleh proses berpikir kreatif yang lebih lengkap, perlu dilakukan penelitian verifikasi dengan: 1) materi yang lain, misalnya dimensi tiga, kombinatorial, limit, differensial, integral, 2) satuan tingkat pendidikan yang berbeda, misalnya siswa SMA kreatif, siswa SMP kreatif, 3) instrumen yang berbeda, misalnya pengajuan masalah 


\section{Histogram: Jurnal Pendidikan Matematika, 3 (2), 2019 - 227 Andi Yunarni Yusri, Febria Hardianty}

\section{DAFTAR PUSTAKA}

Agarwal, S. \& Kumari, S. (1982). A Correlational Study of Risk-Taking and Creativity with Special Reference to Sex Differences. Indian Educational Review, 17, 104-110.

Alimuddin. (2009). Eksplorasi proses berpikir dosen Matematika UNM Makassar dalam pemecahan masalah matematika. Universitas Negeri Makassar.

Alpaugh, P. K. \& Birren, J. E. (1977). Variables Affecting Creative Contributions across the Adult Life Span. Human Development. Human Development, 20(4), 240-248.

Baer, J. (1993). Creativity and Divergent Thinking: A Task Specific Approach. New Jersey: Erlbaum.

Bromley, D. B. (1956). Some Experimental Tests of the Effect of Age on Creative Intellectual Output. Journal of Gerontology, 11, 74-82.

Dharma, S. (2008). Kreativitas. Jakarta: Direktorat Tenaga Kependidikan Direktorat Jenderal Peningkatan Mutu Pendidikan dan Tenaga Kependidikan, Departemen Pendidikan Nasional.

Hwang, W, Y., Chen, N,S., Dung, J, J., \& Yang, Y, L. (2007). Multiple Representation Skills and Creativity Effects on Mathematical Problem Solving using a Multimedia Whiteboard System. Journal of Educational Technology \& Society, 10(2), 191-212.

Jaquish, G. A. \& Ripple, R. E. (1981). Cognitive Creative Abilities and Self-esteem across the Adult Life-Span. Human Development, 24(2), 110-119.

Moleong, L. . (2006). Metodologi Penelitian Kualitatif. Bandung: PT. Remaja Rosda Karya.

Novak, J. D. (1979). Meaningful reception learning as a basis for rational thinking. 1980 AETS yearbook: The psychology of teaching for thinking and creativity. Columbus: $\mathrm{OH}$ : ERIC Clearinghouse for Science, Mathematics, and Environmental Education.

Simonton, D. K. (2003). Scientific Creativity as Constrained Stochastic Behavior: The Integration of Product, Person, and Process Perspectives. Psychological Bulletin, $129(4), 475-494$.

Sriraman, B. (2004). The Characteristics of Mathematical Creativity. The Mathematics Educator, 14(1), 19-34. 